\title{
Distribution and Composition of Aquatic Macrophytes in Santhapettai Lake of Villupuram District in Tamil Nadu
}

\author{
S. Dhanam*, B. Elayaraj \\ Department of Botany, Arignar Anna Government Arts College, Villupuram - 605 602. Tamil Nadu, \\ India.
}
Environmental Science, Department of Botany, Annamalai University, Annamalai Nagar - 608002 , Tamil Nadu, India.

${ }^{*}$ Corresponding author: sdhanam2@gmail.com

Key words: Ecosystem, Macrophytes, Physico-chemical parameters, Santhapettai lake

\begin{abstract}
Macrophytes are important component of the aquatic ecosystem and broad changes in the abundance of individual species and community composition provide valuable information on how and why an ecosystem might be changing. Santhapettai lake is one of the biggest fresh water lake in Villupuram district, Tamil Nadu. The physico-chemical parameters were analysed for one year (October 2012-September 2013). Quadrates were laid randomly and extending from shoreline towards the lake center. The macrophytes falling in each quadrate were sorted species wise, identified and data were recorded. The plants have been identified from fresh materials with the help of different floras. In this present investigation, a total of 33 species belonging to 23 families and 28 genera were identified under algae, pteridophytes, dicotyledons and monocotyledons. Further, the plants were classified in morphological group as floating (7), submerged (1), submerged anchored (13), floating leaved (1) and emergent anchored (11). The coverage/spread of macrophytes along the shorelines was higher compared to the centre of the lakes where the species composition was found reduced. Assessment of biota, continuous monitoring and conservation lake are the important components to safeguard the biological wealth of lentic and lotic freshwater ecosystem.
\end{abstract}

\section{INTRODUCTION}

Biodiversity means the assets of life forms found on earth in the form of millions of different plants, animals and microorganisms, which are further diversified with vast potential of future creation of the biodiversity from the ocean of genomic diversity at the effectively functional level with in living biomass, the genes the contain and the intricate system the form. Biological diversity also means the variability among living organisms from all sources and ecological complexes of which they are part and includes diversity within species or between species and of ecosystem. In aquatic habitat, biodiversity of organisms depend on availability and quality of water. As water is an essence and elixir of life on the earth and that water totally dominates the chemical composition, abundance, productivity and physiological conditions especially the indigenous population of aquatic organisms. Therefore the nature and health of any aquatic community is an expression of quality of water.

Indian subcontinent is very rich in fresh water resources. The Indian fresh waters are under considerable threat owing to the fast face of development. A survey by NEERI shown that $70 \%$ of India's fresh waters are polluted by conventional standards. Although rivers and lakes are most important water resource in India for purpose like drinking water supplies, irrigation and fisheries. Fresh water lakes and reservoirs are also very important water resources in this country and in many areas constitute only available water.

The inland fresh water ecosystem, both lentic and lotic contributes a greater fraction towards the available water resource on the planet which, is now being increasingly subjected to 
greater stress from various human activities. The physico- chemical and biological characteristics of water depends upon several factors including the location of water body, type of sewage and domestic waste disposal, localized human population in surrounding and their activities. As a result large quantities of organic and inorganic nutrients are added. The enrichment of nutrients also occurs due to disposal of domestic and in industrial effluents from surrounding areas, which supports the growth of a variety of macrophytes and microbes in aquatic system. Some of these organisms in aquatic system assume paramount signification either as biological indicator or as an agent in self- cleaning process.

Aquatic plants (macrophytes) are of important component of lake because they provide food and habitat for invertebrates, fishes and wild life. The aquatic plant community or macrophytes comprises a diverse group of macrophyte organisms including angiosperms, ferns, mosses, liverworts, and some fresh water macro algae that occur in seasonally or permanently wet environment. Aquatic macrophytes can be used as tool in the determination of pollution and nutrient level. Submerged macrophytes play key role in the ecology of shallow, alkaline, clear water, lakes, where they form an extensive and diverse littoral community with numerous associated invertebrates, fish and birds (Jeppesen et al., 1993) while the cover and biomass of submerged macrophytes and their role in lake metabolism are largely predictable from lake area, basic configuration and nutrient loading (Gasithe and Hoyer, 1998).

The present study was carried out in the Santhapettai fresh water lake physico-chemical parameters, to assess the wealth of the macrophytes and to find out the dominance of the macrophytes.

\section{MATERIALS AND METHODS}

Santhapettai lake (Lat. $11^{\circ} 96 \mathrm{~N}$; Long $79^{\circ}-20^{\circ} \mathrm{E}$ ) is one of the biggest freshwater lake in Tamil Nadu, South India. It is situated in the western side of Thirukoilur in Villupuram district. The lake is perennial in nature. The mean maximum and minimum temperatures of Villupuram district are $36^{\circ} \mathrm{C}$ and $21^{\circ} \mathrm{C}$ respectively with relative average humidity $83 \%$. The average rainfall is around $1157 \mathrm{~mm}$ with two - thirds of the annual rainfall received during the monsoon season.

The present work is based on the results of Physico-chemical parameters and extensive systematic field studies of the plants of this area for a period of one year (October 2012 to September 2013). Physico-chemical parameters were analyzed, APHA (1998) and Trivedi and Goel (1984) method.

Field trips were made once in a week covering entire lake area with a view to find out the aquatic macrophytes plant species and their ecological features. Quadrates were laid randomly and extending from shoreline towards the lake center. Macrophyte sampling was conducted in June 2013, which forms the peak growth season of the macrophytes. The macrophytes falling in each quadrate were sorted species wise and the number of individuals of each species counted to workout Important Value Index (Frequency, Relative frequency, Density, Relative density, Abundance, Relative abundance)

Angiosperm, pteridophytes and algal macrophytes are observed and collected which include submerged, submerged anchored, floating leaved anchored, emergent anchored and free floating plants. The plants have been identified from fresh materials with the help of different floras (Gamble, Fisher, Flora of presidency of Madras), (Nair, Hendry, Flora of Tamil Nadu, India), (Cook, Aquatic wetland plants of India) and (Subramaniyan, Aquatic angiosperms). The collected specimens were pressed and dried. After drying the plants were mounted on the herbarium sheets and labeled properly for future reference. All the specimens and herbariums were deposited in the laboratory of Botany Department, Arignar Anna Government Arts College, Villupuram. 


\section{RESULTS AND DISCUSSION}

\subsection{Physico-chemical parameters}

The outcomes on a few physico-chemical parameters viz., Air and water temperature, $\mathrm{pH}$, salinity, electrical conductivity, total dissolved solids, total alkalinity, free carbon-dioxide, dissolved oxygen, biological oxygen demand, total hardness, calcium, magnesium, chloride, sulphate, nitrate, potassium and sodium are given in table 1 .

In present study, highest value of air and water temperature $\left(39.5 ; 37.6{ }^{\circ} \mathrm{C}\right), \mathrm{pH}(9.3)$, salinity $(2.9 \mathrm{mg} / \mathrm{L})$, electrical conductivity $(162 \mu \mathrm{S} / \mathrm{cm})$, total dissolved solids $(118 \mathrm{mg} / \mathrm{L})$, total alkalinity $(96 \mathrm{mg} / \mathrm{L})$, dissolved oxygen $(6.1 \mathrm{mg} / \mathrm{L})$, biological oxygen demand $(4.1 \mathrm{mg} / \mathrm{L})$, calcium $(29.4 \mathrm{mg} / \mathrm{L})$, magnesium $(2.34 \mathrm{mg} / \mathrm{L})$, chloride $(5.96 \mathrm{mg} / \mathrm{L})$, nitrate $(2.03 \mathrm{mg} / \mathrm{L})$, potassium $(0.69$ $\mathrm{mg} / \mathrm{L})$, sodium $(6.71 \mathrm{mg} / \mathrm{L})$ were found in summer seasons and free carbon-dioxide $(19.24 \mathrm{mg} / \mathrm{L})$, sulphate $(1.10 \mathrm{mg} / \mathrm{L})$ was observed in monsoon seasons and total hardness $(81 \mathrm{mg} / \mathrm{L})$ was recorded in post monsoon season.

Lowest value of air and water temperature $\left(28.0 ; 23.5^{\circ} \mathrm{C}\right), \mathrm{pH}(7.1)$, salinity $(1.1 \mathrm{mg} / \mathrm{L})$, electrical conductivity $(95 \mu \mathrm{S} / \mathrm{cm})$, total alkalinity $(56 \mathrm{mg} / \mathrm{L})$, potassium $(0.32 \mathrm{mg} / \mathrm{L})$, sodium $(3.67$ $\mathrm{mg} / \mathrm{L})$ were seen in monsoon seasons and total dissolved solids $(76 \mathrm{mg} / \mathrm{L})$, total hardness $(42$ $\mathrm{mg} / \mathrm{L})$, magnesium $(1.45 \mathrm{mg} / \mathrm{L})$, nitrate $(1.36 \mathrm{mg} / \mathrm{L})$ was found in pre monsoon seasons and dissolved oxygen $(3.10 \mathrm{mg} / \mathrm{L})$, biological oxygen demand $(1.9 \mathrm{mg} / \mathrm{L})$, calcium $(11.2 \mathrm{mg} / \mathrm{L})$, chloride $(2.65 \mathrm{mg} / \mathrm{L})$ was recorded in post monsoon seasons and free carbon-dioxide $(8.9 \mathrm{mg} / \mathrm{L})$, sulphate $(0.59 \mathrm{mg} / \mathrm{L})$ was examined in summer seasons.

Table 1 Physico-chemical parameters of Santhapettai lake water during the month of October 2012 to September 2013

\begin{tabular}{|c|l|c|c|c|c|c|c|c|c|c|c|c|c|}
\hline \multirow{2}{*}{ Sl. No. } & \multirow{2}{*}{ Parameters } & \multicolumn{3}{|c|}{ Monsoon } & \multicolumn{3}{c|}{ Post Monsoon } & \multicolumn{3}{c|}{ Summer } & \multicolumn{3}{c|}{ Pre Monsoon } \\
\cline { 3 - 12 } & & $\mathbf{0 c t}$ & Nov & Dec & Jan & Feb & Mar & Apr & May & Jun & Jul & Aug & Sep \\
\hline $\mathbf{0 1}$ & Air Temperature $\left({ }^{\circ} \mathrm{C}\right)$ & 30.0 & 28.5 & 28.0 & 29.0 & 31.0 & 31.5 & 37.4 & 38.2 & 39.5 & 37.9 & 36.2 & 31.1 \\
\hline $\mathbf{0 2}$ & Water temperature $\left({ }^{\circ} \mathrm{C}\right)$ & 26.5 & 24.0 & 23.5 & 24.0 & 28.5 & 29.0 & 35.8 & 36.4 & 37.6 & 35.2 & 34.6 & 29.4 \\
\hline $\mathbf{0 3}$ & $\mathrm{pH}$ & 7.5 & 7.1 & 7.3 & 7.8 & 7.6 & 7.9 & 8.8 & 9.1 & 9.3 & 8.5 & 8.3 & 7.7 \\
\hline $\mathbf{0 4}$ & Salinity $(\mathrm{mg} / \mathrm{L})$ & 1.4 & 1.2 & 1.1 & 2.5 & 1.8 & 2.3 & 2.7 & 2.9 & 2.6 & 1.8 & 1.5 & 1.7 \\
\hline $\mathbf{0 5}$ & Electrical conductivity $(\mu \mathrm{S} / \mathrm{cm})$ & 124 & 118 & 95 & 120 & 130 & 115 & 136 & 162 & 148 & 125 & 112 & 101 \\
\hline $\mathbf{0 6}$ & Total dissolved solids $(\mathrm{mg} / \mathrm{L})$ & 89.5 & 83.2 & 78.6 & 91.5 & 92.1 & 90.0 & 106 & 118 & 102 & 90 & 81 & 76 \\
\hline $\mathbf{0 7}$ & Total alkalinity $(\mathrm{mg} / \mathrm{L})$ & 56 & 63 & 61 & 75 & 72 & 73 & 89 & 96 & 80 & 72 & 85 & 59 \\
\hline $\mathbf{0 8}$ & Free $\mathrm{CO}(\mathrm{mg} / \mathrm{L})$ & 16.08 & 19.24 & 18.92 & 16.42 & 12.13 & 13.94 & 11.2 & 10.5 & 8.9 & 12.5 & 14.2 & 17.2 \\
\hline $\mathbf{0 9}$ & Dissolved oxygen $(\mathrm{mg} / \mathrm{L})$ & 4.40 & 4.70 & 5.15 & 4.85 & 3.10 & 3.80 & 5.75 & 6.10 & 5.90 & 4.25 & 3.90 & 4.15 \\
\hline $\mathbf{1 0}$ & Biological oxygen demand $(\mathrm{mg} / \mathrm{L})$ & 2.8 & 2.2 & 2.7 & 1.9 & 2.5 & 2.3 & 2.9 & 3.4 & 4.1 & 3.6 & 2.7 & 3.4 \\
\hline $\mathbf{1 1}$ & Total hardness $(\mathrm{mg} / \mathrm{L})$ & 57 & 61 & 61 & 81 & 66 & 59 & 62 & 54 & 67 & 42 & 49 & 51 \\
\hline $\mathbf{1 2}$ & Calcium $(\mathrm{mg} / \mathrm{L})$ & 18.3 & 17.5 & 17.3 & 11.2 & 11.9 & 12.4 & 21.3 & 25.8 & 29.4 & 22.1 & 26.9 & 27.7 \\
\hline $\mathbf{1 3}$ & Magnesium $(\mathrm{mg} / \mathrm{L})$ & 1.46 & 1.97 & 1.90 & 1.66 & 1.78 & 1.84 & 1.91 & 2.34 & 2.01 & 1.86 & 1.63 & 1.45 \\
\hline $\mathbf{1 4}$ & Chloride $(\mathrm{mg} / \mathrm{L})$ & 3.20 & 3.22 & 3.25 & 2.65 & 2.80 & 3.16 & 4.8 & 5.96 & 5.63 & 4.91 & 4.84 & 3.62 \\
\hline $\mathbf{1 5}$ & Sulphate $(\mathrm{mg} / \mathrm{L})$ & 0.89 & 0.96 & 1.10 & 0.76 & 0.82 & 0.85 & 0.59 & 0.65 & 0.71 & 0.69 & 0.78 & 0.81 \\
\hline $\mathbf{1 6}$ & Nitrate $(\mathrm{mg} / \mathrm{L})$ & 1.88 & 1.94 & 1.87 & 1.72 & 1.61 & 1.56 & 1.93 & 1.81 & 2.03 & 1.84 & 1.73 & 1.36 \\
\hline $\mathbf{1 7}$ & Potassium $(\mathrm{mg} / \mathrm{L})$ & 0.45 & 0.32 & 0.43 & 0.14 & 0.29 & 0.36 & 0.48 & 0.69 & 0.61 & 0.65 & 0.51 & 0.46 \\
\hline $\mathbf{1 8}$ & Sodium $(\mathrm{mg} / \mathrm{L})$ & 3.95 & 3.84 & 3.67 & 4.61 & 4.90 & 4.82 & 5.92 & 6.5 & 6.71 & 6.6 & 6.1 & 5.8 \\
\hline
\end{tabular}




\subsection{Biological parameters}

In this present investigation, a total of 33 species belonging to 23 families and 28 genera were identified under four classes. Seven species of seven genera and seven families under the class dicotyledons, nine species of eight genera and nine families under the class monocotyledons, six species of six genera and six families under the class pteridophytes, eight species of five genera and three families under the class algae are recorded. Further the aquatic macrophytes classified in morphological group. Among five morpho-ecologic groups, submerged anchored with 13 species dominated the lake followed by emergent anchored (11), floating (7), floating leaved anchored and submerged with one species each. The most dominant families were Hydrocharitaceae and Najadaceae with three species followed by Salviniaceae, Ceratophyllaceae, Characeae, Cyperaceae and Lemmaceae with two species each. Only one species each was recorded for Aponogetonaceae, Commelinaceae, Poaceae, Pontederiaceae, Convolvulaceae, Isoetaceae, Onagraceae, Verbenaceae, Marseliaceae, Araceae, Potamogetonaceae, Polygonaceae, Traphaceae, Typhaceae, and Haloragaceae. The morpho-ecological group of aquatic macrophytes is given in table- 2 . The plants were photographed and given in figure 1. Aquatic macrophytes in the lake occur as submerged anchored (40\%) dominated the lake followed by emergent anchored (33\%), floating (21\%), floating leaved anchored and submerged with 3\% each (figure 2). Important value index (IVI) of the aquatic macrophytes is given in figure 3 .

Presence of Eichornia, Pistia and Ipomoea indicated a clear sign of invasion of alien species in the lake. Narayana and Somashekar (2002) have been conducted that the physico-chemical characters influence the growth of species, distribution, indicator group and Pollution tolerant species. The influence of water chemistry in aquatic plant richness was analysed in several studies. Nicolas et al., (2000) formed that the vegetation response to environmental factors are not always linear. Rorslet (1991) and Murphy (2002) found that the higher macrophytes diversity was observed in mesotrophic to slightly eutrophic lakes. 
Table 2 Morpho-ecological group of aquatic macrophytes recorded in Santhapettai lake October 2012 to September 2013

\begin{tabular}{|c|c|c|c|}
\hline Sl. No. & Name of the plants & Family & Morpho-ecological group \\
\hline 01 & Aponogeton natans (L.) Engl K. Krause & Aponogetonaceae & Floating leaved Anchored \\
\hline 02 & Azolla carolianiana $(\mathrm{L})$. & Salviniaceae & Floating \\
\hline $\mathbf{0 3}$ & Ceratophyllum desmersum (L.) & Ceratophyllaceae & Submerged Anchored \\
\hline 04 & Certophyllum sp. (L.) & Ceratophyllaceae & Submerged Anchored \\
\hline 05 & Chloris barbata (L.) & Poaceae & Emergent Anchored \\
\hline 06 & Chara vulgaris (L.) & Characeae & Submerged \\
\hline 07 & Commelina bengalensis ( L.) & Commelinaceae & Emergent Anchored \\
\hline 08 & Cyperus articulatus (L.) & Cyperaceae & Emergent Anchored \\
\hline 09 & Cyperus rotundus (L.) & Cyperaceae & Emergent Anchored \\
\hline 10 & Eichhornia crassipes (Mart) Solms & Pontederiaceae & Floating \\
\hline 11 & Hydrilla verticillata (L.F) Royle & Hydrocharitaceae & Submerged Anchored \\
\hline 12 & Hydrilla sp. (L.) & Hydrocharitaceae & Submerged Anchored \\
\hline 13 & Ipomoea carnea (Jacq.) & Convolvulaceae & Emergent Anchored \\
\hline 14 & Isoetes Sp. (L.) & Isoetaceae & Submerged Anchored \\
\hline 15 & Jussiaea repens (L.) & Onagaraceae & Emergent Anchored \\
\hline 16 & Lemna gibba $(\mathrm{L})$. & Lemnaceae & Floating \\
\hline 17 & Lippia nudiflora (L.) & Verbenaceae & Emergent Anchored \\
\hline 18 & Marsilea quadrifolia (L.) & Marsilaceae & Emergent Anchored \\
\hline 19 & Myriphyllum aquaticum (L.) & Haloragaceae & Submerged Anchored \\
\hline 20 & Najas gramineae Delile & Najadaceae & Submerged Anchored \\
\hline 21 & Najas minor All & Najadaceae & Submerged Anchored \\
\hline 22 & Najas sp. (L.) & Najadaceae & Submerged Anchored \\
\hline 23 & Nitella hylina (L.) & Characeae & Submerged Anchored \\
\hline 24 & Nelumbo nucifera (Gaerth Fruct) & Nymphaceae & Submerged Anchored \\
\hline 25 & Nymphaea pubescens (L.) & Nymphaceae & Submerged Anchored \\
\hline 26 & Pistia stratiotes (L.) & Araceae & Floting \\
\hline 27 & Potamogeton nodosus (L.) & Potamogetonaceae & Emergent Anchored \\
\hline 28 & Polygonum glabrum (Willd) & Polygonaceae & Emergent Anchored \\
\hline 29 & Salvinia natans (L.) & Salviniaceae & Floting \\
\hline 30 & Spirodela polyhize (L.) & Lemnaceae & Floting \\
\hline 31 & Trapha natans (L.) & Traphaceae & Floting \\
\hline 32 & Typha angustifolia (L.) & Typhaceae & Emergent Anchored \\
\hline 33 & Vallisneria natans (L.) & Hydrocharidaceae & Submerged Anchored \\
\hline
\end{tabular}

In the present study the monocots predominant over dicots with respects to species, genera and family. Anand and Sharma (1993) also reported that in lotic water bodies monocot dominated the dicot. Such a dominance of monocots over the dicots in aquatic habitates has already been emphasized by a number of works (Muencher, 1994 and Hutchinson, 1975). Predominance of monocots in an aquatic ecosystems is due to the high degree of polyploidisation, consequently increased the seed size, tendency to reproduce vegetatively and resistance to herbivores (Kautsky, 1989). Growth of emergents becomes very dense with eutrophication (Moss, 1979) and with the increase in the alkalinity of lakes, the floating leaf species get replaced by emergent macrophyte (Makela et al., 2004). The studied lakes are shallow lakes, which provide suitable habitat for the growth of emergent vegetations (Pandit, 2010). 


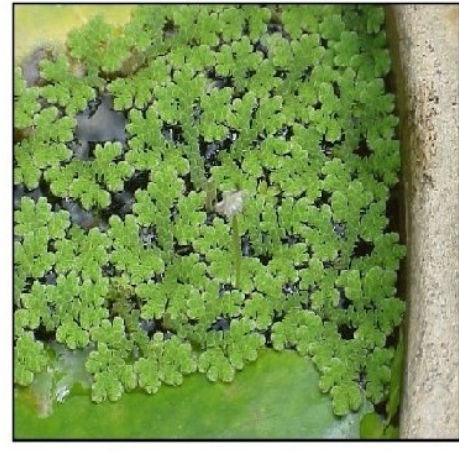

Azolla carolianiana (L.)

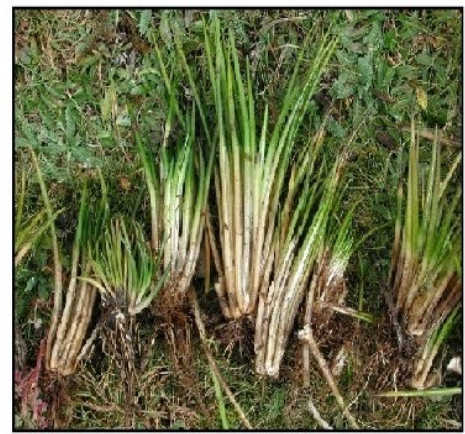

Isoetes sp., (L.)

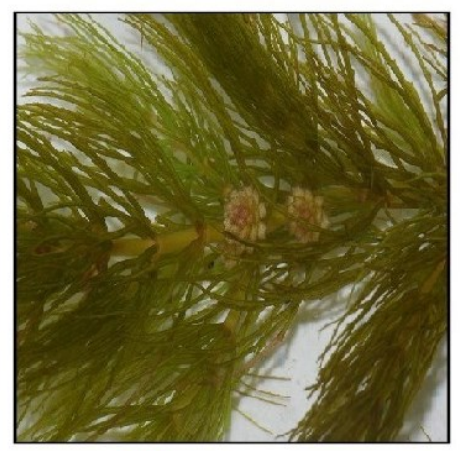

Ceratophyllum desmersum (L.)

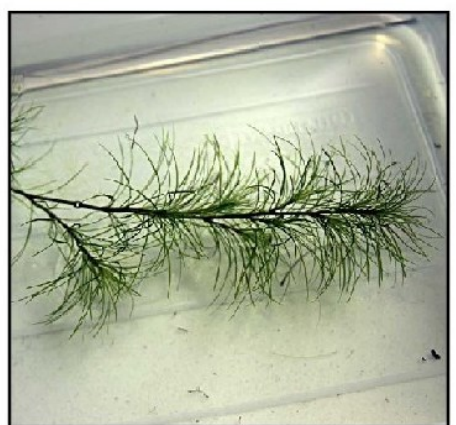

Najas graminea (Delile)

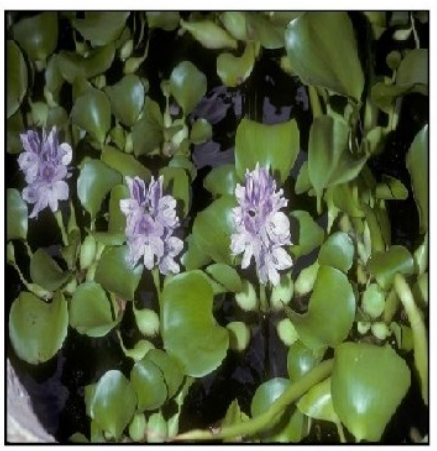

Eichhornia crassipes (Mart) Solms.

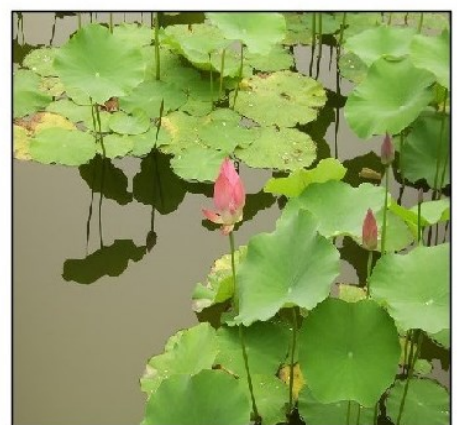

Nelumbo nucifera (Gaerth.Fruct)

Figure 1 Photograph of Aquatic macrophytes in Santhapettai lake

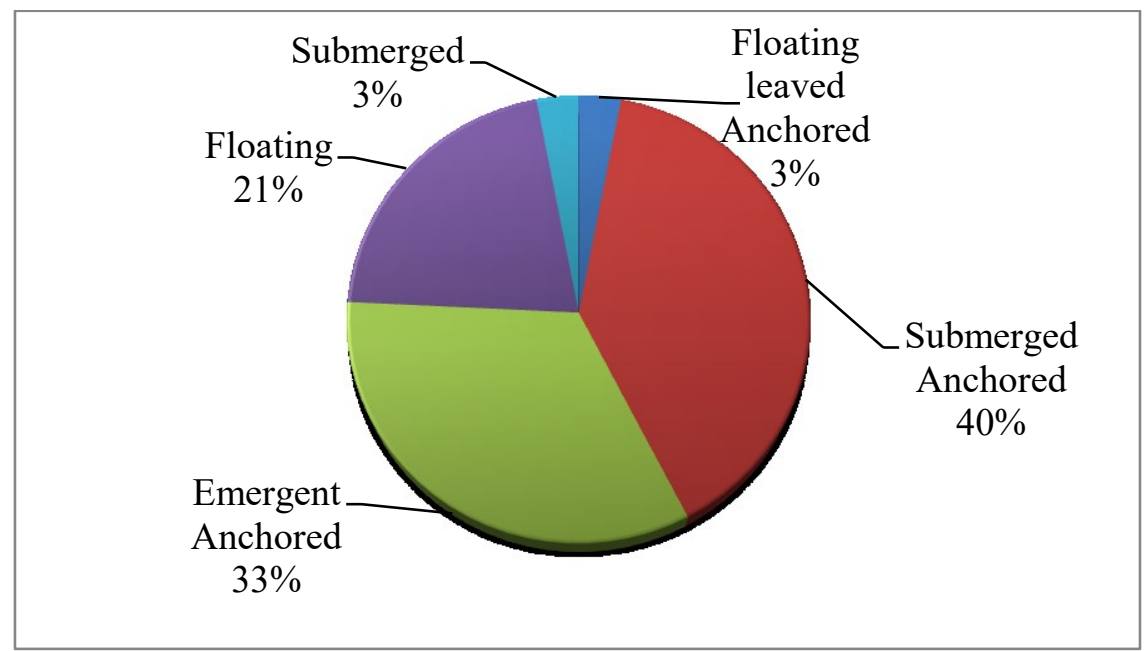

Figure 2 Percentage (\%) of Aquatic macrophytes distribution in Santhapettai lake 


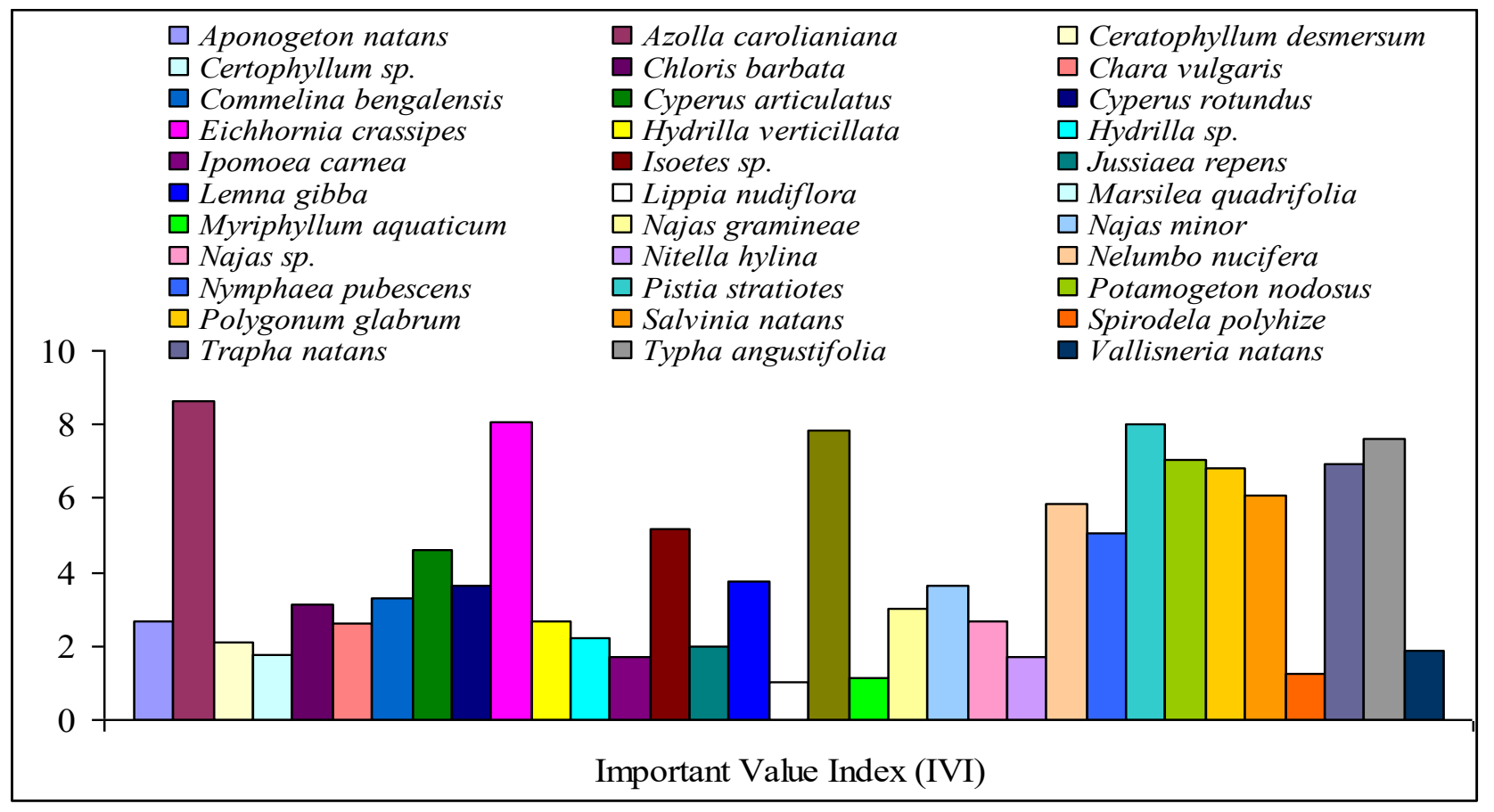

Figure 3 Important value index (IVI) of Aquatic macrophytes in Santhapettai lake

\section{CONCLUSION}

Inhabitants around the lake are unaware about the importance of flora and fauna. Qualitative and quantitative floristic survey, constant monitoring and protection of lentic and lotic ecosystems are the need of the hour in order to save the native biota, to maintain the quality of drinking water, and disqualify the efforts of alien species to invade.

\section{References}

[1] Anand, V. K and S. Sharma, 1993. Occurrence, distribution and composition of aquatic and marshy plants of Jammu province. Environ. and Ecol., 11 (1): 109-114.

[2] APHA, 1998. Standard methods for the examination water and waste water $20^{\text {th }}$ Ed., American Public Health Association, New York, USA.

[3] Cook, C. D. K. 1996. Aquatic and wetland plants of India, Oxford University Press, New York, pp. 385.

[4] Gamble, J. S and C. E. S. Fischer (1921-1935). Flora of presidency of Madras. Vol. 1-3, Adlard and Son Ltd., London, 1-2017.

[5] Gasith, A and M. V. Hoyer, 1998. Structuring role of macrophytes in lakes; changing influence along lake size and depth gradients. In the structuring role of submerged macrophytes in lakes. Ecological Studies 131. Edited by. E. M .New York. pp. 381-392.

[6] Hutchinson, G. E. 1975. A treatise on limnological botany. Jhon Wiley \& Sons, New York.

[7] Jeppesen, E., T. L. Lauridsen, T. Kairesalo and M. R. Perrow, 1998. Impact of submerged macrophytes on fish-zooplankton interaction in lakes. New York. pp. 91-114. 
[8] Kautsky, L. 1989. Seed and tuber banks of aquatic macrophytes in the Asko area, Northern Baltic proper. Holaract, Ecol., 13: 143-148.

[9] Makela, S, E. Haitu and L. Arvola, 2004. Spatial patterns in aquatic vegetation composition and environmental covariates along chains of lakes in Kokemaenjoki watershed (S.Finland). Aquatic Botany, 80: 253-269.

[10] Moss, B. 1979. Algal and other fossils evidence for major changes in Stumps haw Broad, Norfolk England in the last two centuries. Br. Phycol. J. 14: 253-283.

[11] Muenscher, W. L. 1994. Aquatic plants of the United States. Comstock Publ. Corp., New York.

[12] Murphy, K. J. 2002. Plant communities and plant diversity in soft waters lakes of Northern Europe. Aquatic Botany. 73: 287-324.

[13] Nair, N. C. and A. N. Hendry, 1983. Flora of Tamil Nadu. India Series 1. Vol. 1 Botanical survey of Indian, Southern Circle, Coimbatore, India. 1-184.

[14] Narayana J, R. K. Somashekar, 2002. Macrophytic diversity in relation to water quality. Investigation on River Cauvery. In: Ecology and conservation of lakes, reservoir and rivers ABD Publishers, Jaipur, India.

[15] Nicolas, S., S. Weber and B. Shaw, 2000. A proposed aquatic plant community biotic index for Wisconsin lakes. Environ. Management. 26: 491-502.

[16] Pandit, A. K., G. A. Mir and Dilafroza Jan. 2010. Phytosociology of Macrophytes in MirgundWetland of Kashmir Himalaya. J. Himalayan Ecol. Sustin. Dev. 5: 150-156.

[17] Rorslet, B. 1991. Principal determinants of aquatic macrophytes richness in northern European lakes. Aquatic Botany. 39: 173-193.

[18] Subramaniyan, K. 1962. Aquatic angiosperms. C.S.I.R. Publications, New Delhi, India.

[19] Trivedy, R. K and P. K. Goel, 1984. Chemical and biological methods for water pollution studies. Environmental Publishers, Karad, India. pp. 340. 